\title{
Neuroimmunological features in premature infants with perinatal infections
}

\author{
Rahimova N.J. \\ Scientific Research Institute of Pediatrics named after K.Y. Farajova, Baku, Azerbaijan
}

\begin{abstract}
.
Background: The purpose of this study was to examine the neurological status, taking into account the neuroimmunological indicators (neuron-specific enolase (NSE), interleukin-1 $\beta$ (IL-1 $\beta$ ), Interleukin-6 (IL-6) in the serum of neonates with perinatal infections. Methods: We conducted a complex clinical, laboratory and instrumental examination of 433 infants with perinatal infections with a gestation period of 27-37 weeks. Determination of the level of NSE, IL-1 $\beta$, IL-6 was performed with the standard method of the immune-enzyme analysis. Hypoxic ischemic, hemorrhagic, infectious lesions of the central nervous system (CNS) were more common in newborns with concomitant infection and sepsis. High levels of NSE, IL-6, IL-1 $\beta$ in the serum of the examined newborns reflect a combined, deeper character of the CNS damage. Conclusion: A good diagnostic value of neuroimmunological indicators in the blood serum of newborns with perinatal infections makes it possible to use them as a marker for assessing the severity of the CNS lesions.
\end{abstract}

Keywords: perinatal infections, preterm infants, neuron-specific enolase, cytokines.

Perinatal infection is one of the important and complex medical problems of modern neonatology and leading cause of morbidity and mortality among newborns [1,2]. Intrauterine infections are chronic in $80 \%$ of cases and are cause of death of $61.8 \%$ of premature newborns and $49.7 \%$ of term newborns [3].

Despite the significant improvment in understanding of mechanisms leading to development of perinatal infections in newborns, they continue to be one of the main causes of severe neurological injury at birth [4,5]. The intrinsic difficulty of newborn assessment makes it requirement to employ wide range of noninvasie diagnostic methods, including ultrasonography of brain, as well as laboratory tests, including testing for neuronspecific proteins (NSP), enabling to objectively determine and assess the degree of structural changes that can also be secondary to infection of CNS. It is well known that neuronspecific enolase (NSE) is considered as one of the most specific markers of neuron damange. It is used as an indicator of degree of neuron injury and overall changes in permeability of blood-brain (hematoencephalic) barrier [6].

The important pathogenetic role that neuroinflammation plays in CNS disorders, 
makes it possible to use the level of proinflammatory cytokines as indicators for determination of the severity of CNS injury [710]. According to the available research, the high levels of proinflammatory cytokines in hypoxicischemic encephalopathy is not only an indicator of severity of brain injury in newborns, but is an additional noxious factor [5,11].

Therefore, research into the dynamics of neurospecific proteins, immuncytokines, determination of their diagnostic and prognostic value in perinatal CNS disorders among newborns with perinatal infections is of paramount interest.

\section{Objective of research: determine the} neurological state of newborns with perinatal infections in relation with neuroimmunological indicators including neurospecific enolase, IL-1 $\beta$, and IL- 6 .

Materials and research methods: Research team conducted clinical and laboratory evaluation of 433 premature newborns with gestational age ranging from 27 to 37 weeks with perinatal infections admitted to the departments of diseases of premature newborns, anesthesiology, reanimathology and intensive care of Scientific-research Institute of Pediatrics after K.Y.Faradjova during period of 2012-2017. Based on the results of comprehensive evaluation and ethiology of the disease, the newborns with infections were divided into 3 groups:

I qroup: 220 newborns with intrauterine CMV infection;

II qroup: 118 newborns with mixed infection;

There was 85 newborns with CMV and HSV-2, 8 newborns with CMV and toxoplasmosis, 25 newborns had CMV and bacterial infection (neonatal sepsis). Bacteriological examination of the blood revealed 50 children $(52,6 \pm 5,1 \%)$ with Staphylococcus aureus, $18(18,9 \pm 4,0 \%)$ - with Streptococcus spp., $11(11,6 \pm 3,3 \%)$ - with Klebsiella spp., $15 \quad(12,3 \pm 3,0 \%)$ - with Escherichia coli. All pathogens were present in concentrations of 105-107 colonyforming units per $1 \mathrm{ml}$. Newborn weight ranged from 800 grams to 2500 grams and averaged as $2035,9 \pm 27,8$. Among children included in the study, there were $246(56,8 \%)$ boys, and $187(43,2 \%)$ girls. Gestational age varied from 27 to 37 weeks and averaged as $33,9 \pm 0,1$. Among them, there were $222(51,3 \pm 2,4 \%)$ children of 37 35 gestational age, $127(29,3 \pm 2,2 \%)$ children of 34-32 gestational age, $127(29,3 \pm 2,2 \%)$ - of 3129 gestational age, $17(3,9 \pm 0,9 \%)$ - of $28-27$ gestational age. The age of pregnant women varied from 17 to 43 years old and averaged $22,6 \pm 2,0$ years old. There were $277(64,0 \pm 2,3 \%)$ prima gravida and $156(36,1 \pm 2,3 \%)$ with more than one pregnancy. The control group included 33 relatively healthy newborns without intrauterina infections. Gestational age of newborns in control group ranged from 30 to 37 weeks and averaged 34,8 $\pm 0,2$ weeks. The weight of newborns varied between 2000 and 3170 grams and averaged $2259,1 \pm 38,7$ grams. There were $5(15,2 \%)$ boys and $28(84,8 \%)$ girls in the healthy group. The height of children varied from $39 \mathrm{sm}$ to $52 \mathrm{sm}$, averaging $46,2 \pm 0,6 \mathrm{sm}$; the head circumference ranged from 28 to $36 \mathrm{sm}$ and averaged $31,6 \pm 0,3 \mathrm{sm}$; chest circumference ranged from 26 to $34 \mathrm{sm}$ averaging $30,0 \pm 0,3 \mathrm{sm}$.

All children received comprehensive dynamic clinical examination, laboratory evaluation, biochemical and bacteriological tests of blood, urine and stool (per indications). Verification of ethiological diagnosis was made by immunoenzyme analysis on Sirio (Italy) 
laboratory equipment with use of reactants of Nova-Lisa firm (Germany) through testing for specific IgM, IgG type antibodies against CMV, HSV-1 and HSV-2. The detection of infectious agents by PCR in biological fluid samples (blood, saliva, urine) were also performed for confirmation of congenital infection.

Determination of neurospecific enolase (NSE), IL-1 $\beta$, IL-6 was performed using standart method of solidphase («sandvich» variant) of immunoenzyme analysis by using the diagnostic test systems by «Vektor-Best» (Novosibirsk, RF) on ElisysUnoHuman analyser (Germany).

Statistical analysis of the obtained results were completed per modern requirements and included one-way analysis of variance by Kruskall-Wallis, correlational using $\rho$-Spirman, discriminative analysis using "Cut of Point", dispersion analysis using ANOVA and ROC-analysis. We used EXCEL2010 and SPSS-20 to conduct statistical data analysis.

\section{Results and discussion:}

The research included the analysis of patient records, prenatal and intranatal risk factors, as well as prevalence of pathogens causing perinatal infection among observed children. The impact of maternal, fetal and newborn-related factors to the development of perinatal infections, the one way analysis of variance based on non-parametric criteria by Kurskall-Wallis test for determinational ofthe prevalence of these factors among the studied groups was performed. The differences between the compared parameters were statistically significant with $\mathrm{p}<0,05$.

Following the analysis of health status and details of somatic anamnesis of mothers of premature babies with perinatal infections, we found that $253(58,4 \pm 2,4 \%)$ had extragenital pathologies which was higher than among mothers of healthy babies $\left(\chi^{2}=19,3 ; \mathrm{F}=15,2\right.$; $\mathrm{p}<0,001)$. Analysis of obstetric anamnesis demonstrated that majority of mothers of premature babies with perinatal infections (205 $(47,3 \pm 2,4 \%))$ had gynecological diseases $\left(\chi^{2}=23,2 ; \quad \mathrm{F}=18,9 ; \mathrm{p}<0,001\right)$. Among mothers with complicated obstetrical anamnesis there was statistically significant prevalence of stillbirthes $\left(\chi^{2}=19,2 ; \mathrm{p}<0,001 ; \mathrm{F}=1,46 ; \mathrm{p}=0,225\right)$ comparing with medical abortions $\left(\chi^{2}=2,3 ; \mathrm{p}=0,511\right)$, with prenatal fetal death $\left(\chi^{2}=4,6 ; p=0,198\right)$. As the comorbidities complicating the pregnancy, the gestosis of second half of pregnancy was found in $151(34,9 \pm 2,3 \%)$ cases $\left(\chi^{2}=39,4 ; \quad \mathrm{p}<0,001\right.$; $\mathrm{F}=3,71 ; \mathrm{p}=0,012)$, pregnacy termination concern - among $104(24,0 \pm 2,1 \%)$ cases $\quad\left(\chi^{2}=46,7\right.$; $\mathrm{p}<0,001 \mathrm{~F}=1,4 ; \mathrm{p}=0,241)$ and anemia was found among $301(69,5 \pm 2,2 \%)$ cases $\left(\chi^{2}=50,9 ; p<0,001\right.$ $\mathrm{F}=1,01 ; \mathrm{p}=0,36)$.

Complicated labour and delivery, surgical delivery and number of mothers with infections were statistically significant.

Syndrom of CNS depression was found to be most prevalent neurological diagnosis that was reported equally in all three groups, including control group. It is important to indicate that analysis of main neurological syndromes of neonatal period revealed that seizures were noted among $32(27,1 \pm 4,1 \%)$ premature newborns with mixed infection and among $24(25,3 \pm 4,5 \%)$ with sepsis. Tonic-clonic seizures were most prevalent in these groups. Seizures were found among 28 $(12,7 \pm 2,2 \%)$ children with CMV infection. Our research also demonstrated that hypertensive syndrom $32(27,1 \pm 4,1 \%)$ is more prevalent among premature newborns. 
Although the syndrome of autonomousvisceral disorders was found in all three groups of newborns, however it was statistically more prevalent in the group with bacterial infection $23(24,2 \pm 4,4 \%)$.

The analysis of clinical data showed that clinical condition of newborns at birth as well as during the next days of life remained severe and very severe. Therefore it is extremely difficult to define the neurological syndromes of CNS injury. The severity of general clinical condition along with morphological and functional immaturity secondary to premature birth conceal neurological syndromes. This highlights the importance of complete and comprehensive evaluation with the goal of early differential diagnosis of CNS disorders and development of treatment strategies.

Analysis of neurosonographic data demonstrated that percentage of intracerebral bleeding was higher in the group of premature newborns with CMV infection and sepsis (table 1). It was revealed that premature newborns with intrauterine infections had concomittant CNS lesion such as intraventricular hemorrhages, which was partly attributed to hypoxia, partly to the injurious impact of toxins on the vascular wall leading to the increased permeability and in anatomically "weak spots" (periventricular zones) also causing the damage to vasculature and development of hemorrages.

Hemodynamic changes of infectious origin were equally reported in all groups of premature newborns: $\quad 34(15,5 \pm 2,4 \%) ; \quad 20(16,9 \pm 3,5 \%)$; $18(18,9 \pm 4,0 \%)$. Analysis of neurosonography demonstrated that ventriculitis occured more often among newborns with CMV and sepsis, while the meningitis - among children with mixed and bacterial infection.
Although ventriculomegaliy (enlargement of horns of lateral ventricules) of various severity, including hydrocephalus, was equally diagnosed among newborns with infection, however it occured more often in II group $30(25,4 \pm 4,6 \%)$ and III groups $22(23,4 \pm 4,4 \%)$. These findings represent very severe pathological processes (intracranial hemorrhages, intrauterine infections of the brain among premature newborns with low birth weight.

Pathological neurosonographic signs (calcifications, cysts, mineralising vasculopathy) were reported less among evaluated premature newborns in groups I and II than among term newborns. Thus, calcifications in group I were reported among $13(7,3 \pm 2,0 \%)$ term newborns and $9(4,1 \pm 2,0 \%)$ of prematurely born babies, in group II it was respectively $9(4,1 \pm 2,6 \%)$ and $14(11,9 \pm 3,0 \%)$. Mineralising vasculopathy occured more often in the group of premature newborns with mixed infection.

Evaluation of children with intrauterine infections showed that 14 premature newborns with defects of brain development had other developmental defects, 2 children $(0,9 \pm 0,6 \%)$ had CMV infection, $11(0,8 \pm 0,8 \%)$ had mixed infection and $2(0,9 \pm 0,6 \%)$ newborns had sepsis.

\section{Table 1.}

Sonographic signs of cerebral pathology in premature newborns with perinatal infection. (see Annex)

Hypoxic ischemic, hemorrhagic, infectious lesion of CNS occured more often in newborns with mixed infection and sepsis. Concentrations of NSE in the plasma of children were determined on 5-7th day of life in the acute phase of disease upon admission to the ward and 
again on 25-28th day of life (upon completion of neonatal period). The level of NSE in the plasma of healthy premature newborns was $6,0 \pm 0,8$ $\mathrm{ng} / \mathrm{L}$, while in premature babies with $\mathrm{CMV}$ infection it was 3.4 times higher averaging $20,3 \pm 1,3 \mathrm{ng} / \mathrm{L}$. Our research showed 4.9 fold increase in the levels of NSE in the late neonatal period compared with early neonatal period $(29,6 \pm 2,5 \mathrm{ng} / \mathrm{L}$ and $20,7 \pm 1,8 \mathrm{ng} / \mathrm{L}$ respectively) in premature newborns with mixed infection. The levels of NSE was 3.4 fold higher in prematurely born babies with sepsis in comparison with control group $(p<0,001)$. In early neonatal period the level of NSE ranged between 7,9 and 31 ng/L, averaging 20,3 $\pm 1,9 \mathrm{ng} / \mathrm{L}$. Monitoring of NSE level demonstrated constantly higher levels averaging $18,0 \pm 1,5 \mathrm{ng} / \mathrm{L}$, and it did not normalize by the ned of neonatal period.

The characteristics of cytokine status in newborns with perinatal infection was studied using criteria of Kruskel-Wallis and revealed the statistically significant increase in level of proinflammatory cytokines in comparison with that of control group: IL-6 - 5.4 fold increase $\left(\chi^{2}=33,9 ; \mathrm{p}<0,001\right)$, IL-1 $\beta-5.5$ fold increase $\left(\chi^{2}=27,0 ; p<0,001\right)$,

Highest level of IL-1 $\beta$ was demonstrated in premature babies with $\mathrm{CMV}$ and bacterial infections, while premature babies with mixed and bacterial infections had highest level of IL- 6 .

Table 2.

Neuroimmunological indicators of blood in premature newborns with perinatal infections. (see Annex)

While analysing the levels of NSE in premature babies, we defined the area under curve ROC, standart error, defined upper and lower limits of
CI $95 \%$ as well as asymptomatic levels (CI). According to the levels of NSE the area under curve was $\mathrm{S}=0,971 \pm 0,022$ (95\%CI: 0,928-1,000; $\mathrm{p}<0,001), \quad$ IL-1 $\beta$ in premature babies $\mathrm{S}=0,990 \pm 0,012$ (95\% CI: 0,966-1,00; $\mathrm{p}<0,001)$, IL-6 - S=1,000 $\pm 0,000$ (95\% CI: 1,000-1,000; $\mathrm{p}<0,001)$.

To determine the prognostic value of NSE based on coordinates of ROC, we defined the cut-of-points that reflects the point when total values of sensitivity and specificity reaches the maximum level. The optimal cut-of-point of NSE in prematurely born babies was $11 \mathrm{pg} / \mathrm{ml}$. At this point the sensitivity was equal (Se) $85,3 \pm 6,1 \%$ and specificity (Sp) - 90,0 $\pm 9,5 \%$. Optimal cutof-point forlL-1 $\beta$ was $3,5 \mathrm{pg} / \mathrm{ml}$. At this point, the sensitivity (Se) is equal to $97,1 \pm 2,9 \%$, specificity (Sp) - 90,0 $\pm 9,5 \%$; while for IL $-6 \geq 4$ $-\mathrm{Se}=100,0 \%, \mathrm{Sp}=90,0 \pm+9,5 \%$.

Table 3.

«Cut-of-points» for NSE, IL-1及, IL-6 in premature newborns with perinatal infections.

\begin{tabular}{|c|c|c|c|}
\hline & $\mathrm{NSE} \geq 11$ & IL-1 $>3,5$ & IL-6>4 \\
\hline $\begin{array}{l}\text { Sensitivity }- \text { true }(+) \\
\text { results Se }\end{array}$ & $85,3 \pm 6,1$ & $97,1 \pm 2,9$ & $\begin{array}{l}100,0 \pm 90 \\
, 0\end{array}$ \\
\hline $\begin{array}{l}\text { Specificity - } \\
\text { true (-) results Sp }\end{array}$ & $90,0 \pm 9,5$ & $90,0 \pm 9,5$ & $90,0 \pm 9,5$ \\
\hline $\begin{array}{l}\text { Predictive value } \\
(+) \text { results pPV }\end{array}$ & $96,7 \pm 3,3$ & $97,1 \pm 2,9$ & $97,1 \pm 2,8$ \\
\hline $\begin{array}{l}\text { Predictive value } \\
\text { (-) results } \mathrm{nPV}\end{array}$ & $64,3 \pm 12,8$ & $90,0 \pm 9,5$ & $\begin{array}{l}100,0 \pm 0, \\
0\end{array}$ \\
\hline $\begin{array}{l}\text { Likelihood ratio } \\
(+) \text { results LR+ }\end{array}$ & 8,53 good & 97,1 good & $\begin{array}{l}10,00 \\
\text { good }\end{array}$ \\
\hline $\begin{array}{l}\text { Likelihood ratio } \\
\text { (-) results LR- }\end{array}$ & 0,16 good & $\begin{array}{l}0,03 \\
\text { excellent }\end{array}$ & $\begin{array}{l}0,00 \\
\text { excellent }\end{array}$ \\
\hline $\begin{array}{l}\text { Overal diagnostic } \\
\text { value of the test } \\
\text { DK }\end{array}$ & $86,4 \pm 5,2$ & $95,5 \pm 3,1$ & $97,7 \pm 2,2$ \\
\hline
\end{tabular}


Overal diagnostic value of the NSE test was $86,4 \pm 5,2 \%$, of IL- $1 \beta-95,5 \pm 3,1 \%$, of IL-6 $97,7 \pm 2,2 \%$. This confirms their overall good diagnostic efficiency.

Further we used one factor dispersion analysis ANOVA (Analysis of variance) and determined that weight of factor for values of $\mathrm{NSE} \geq 11$ was $84,8(95 \% \mathrm{CI}: 86,3-83,3 ; \mathrm{p}<0,001)$, for IL-1 $\beta>3,5$ weight of factor was $313,1 \quad(95 \%$ CI:333,8-292,4; $\mathrm{p}<0,05)$, for IL-6>4,0 weight of factor was $695,5 \% \quad(95 \%$ CI $\quad 753,2-637,7$; $\mathrm{p}<0,001)$,

In premature newborns with perinatal infections we used correlational analysis by $\rho$ Spirmen and determined several associations between the lesions of CNS, NSE and other parameters defining the severity of the disease. The level of NSE was found to be in direct average correlation with anemia of prematurity which was defined by lower than normal $\mathrm{Hb}$ $\left(\rho_{\mathrm{s}}=0,508, \mathrm{p}=0,001\right)$ and erythrocytes $\left(\rho_{\mathrm{s}}=0,355\right.$, $p=0,27)$. Level of NSE is dependant from hyperproduction of IL $-1 \beta\left(\rho_{\mathrm{s}}=, 584, \mathrm{p}<0,001\right)$, IL$6 \quad\left(\rho_{\mathrm{s}}=, 450, \mathrm{p}=0,001\right)$. Correlational analysis demonstrated the direct average association between CNS lesion $\left(\rho_{\mathrm{s}}=, 501, \mathrm{p}<0,001\right)$ and weak association with infections of CNS $\left(\rho_{\mathrm{s}}=, 353, \mathrm{p}=0,019\right)$.

The premature birth of children with perinatal lesion of CNS was associated with complicated antenatal period, including: gynecological diseases $\left(\rho_{\mathrm{S}}=0,101, \mathrm{p}=0,30\right)$, anemia of pregnancy $\left(\rho_{S}=0,116, p=0,030\right)$, extragenital pathologies $\left(\rho_{\mathrm{S}}=0,131, \mathrm{p}=0,005\right)$. Hypoxic injury of CNS was negatively associated with the antropometric parameters at birth. These babies had smaller birth weight $\left(\rho_{\mathrm{S}}=-0,098\right.$, $\mathrm{p}=0,035)$, height $\left(\rho_{\mathrm{S}}=-0,119, \mathrm{p}=0,013\right)$, Apgar score at 1 st minute $\left(\rho_{S}=-0,485, p<0,001\right)$ and 5 th minute $\left(\rho_{S}=-0,440, p<0,001\right)$, hemoglobin level $\left(\rho_{\mathrm{S}}=-0,174, \mathrm{p}<0,001\right)$ and $\mathrm{RBC}$ count $\left(\rho_{\mathrm{S}}=-0,156\right.$, $\mathrm{p}<0,001)$. Direct correlation was identified between CNS lesion and elevate level of bilirubin уровня билирубина $\left(\rho_{\mathrm{S}}=0,256, \mathrm{p}<0,001\right)$, IL$1 \beta\left(\rho_{\mathrm{s}}=, 579, \mathrm{p}<0,001\right)$, IL-6 $\left(\rho_{\mathrm{s}}=, 547, \mathrm{p}=0,003\right), \mathrm{IL}-$ $18\left(\rho_{\mathrm{s}}=, 514, \mathrm{p}<0,001\right), \mathrm{TNF}-\alpha\left(\rho_{\mathrm{s}}=, 363, \mathrm{p}=0,016\right)$.

The clinical data analysis showed that perinatal infections were more often associated with neurological disorders that included hypoxic-ischemic, hypoxic-hemorrhagic lesions and CNS infections. Identified correlation between the levels of NSE and cytokines demonstrates the ongoing acute systemic inflammatory reaction to the infectious agent amid the severe CNS injury.

Conclusion: We used comprehensive approach including clinical, echo and doppler study, immunological studies in newborns with perinatal infections to provide for timely prognostic evaluation of severity of CNS damage. It seems that higher levels of NSE, IL-6, IL- $1 \beta$ in the plasma of newborns with infectious and inflammatory diseases reflect the concomittant, more severe lesion of CNS as the result of hypoxia, intoxication and inflammation. Thus, the good diagnostic value of neuroimmunological indicators found in plasma of newborns with perinatal infections enables to use them as markers of damange to blood-brain barrier, provide for timely prognostic evaluation, define the severity of CNS injury and commence early treatment.

\section{CONFLICT OF INTEREST STATEMENT}

The authors have no conflicts of interest to declare.

\section{FUNDING}


Uptodate In Medicine LLC funded translation and editorial support for Azerbaijan language. There is no other source of funding to report for this case report.

\section{ETHICAL APPROVAL}

No ethical approval was required as this was a clinical case.

\section{CONSENT}

Patient permission was obtained prior to writing this report.

\section{Literature}

1. Царегородцев А. Д., Ружицкая Е. А., Кистенева Л. Б. Персистирующие инфекции в педиатрии: современный взгляд на проблему// Российский вестник перинатологии и педиатрии, том 62, №1,2017, c.5-9. [Tsaregorodtsev A. D., Ruzhitskaya E. A., Kisteneva L. B. Persistiruyushchie infektsii $\mathrm{V}$ pediatrii: sovremennyi vzglyad na problemu// Rossiiskii vestnik perinatologii i pediatrii, tom 62, №1,2017, s.5-9. (In Russ.)].

2. Bale J.F.Jr. Cytomegalovirus infections. Semin Pediatr Neurol 2012; 19: (3): 101-106.

3. Нисевич Л.Л.,Талалаев А.Г., Каск Л.Н. и др. Причины мертворождения и смерти новорожденных, умерших в течение первых суток жизни, по материалам аутопсии и вирусологических исследований //Вопросы практической педиатрии. Материалы Ежегодного Конгресса перинатальной медицины Современная перинатология: организация, технология и качество (Москва, 27-29 сентября 2010 года), т.5, Приложение № 1.
- C. 56. [Nisevich L.L., Talalaev A.G., Kask L.N. i dr. Prichiny mertvorozhdeniya i smerti novorozhdennykh, umershikh $\mathrm{v}$ techenie pervykh sutok zhizni, po materialam autopsii i virusologicheskikh issledovaniy. Voprosy prakticheskoy pediatrii. Materialy V Ezhegodnogo Kongressa perinatal'noy meditsiny «Sovremennaya perinatologiya: organizatsiya, tekhnologiya i kachestvo». Moskva, 27-29 sentyabrya 2010 goda [Questions of practical pediatrics. Proceedings of the $\mathrm{V}$ annual congress of perinatal medicine «Modern perinatal medicine: organization, technology and quality». Moscow, 27-29 September, 2010]. 2010, Vol. 5, Supplement no. 1, p. 56. (In Russ.)].

4. Долгих Т.И., Белкова Т.Н., Тирская Ю.И. и др. Клинико-иммунологические аспекты внутриутробных инфекций с поражением центральной нервной системы у новорожденных //Цитокины и воспаление, 2011, № 1, c.12-17. [Dolgih T.P., Belkova T.N., Tirskaja Yu.I. et al Clinical and immunological aspects of intrauterine infections with central nervous system damage in newborns. Citokiny $i$ vospalenie. $2011 ; 10$ (1): 46-50. (In Russ.)].

5. Мамедбейли А.К. Сравнительная характеристика поражений центральной нервной системы у новорожденных с внутриутробными инфекциями различной этиологии // Вопросы практической педиатрии. - 2010. - №3. - С. 95-96. [Mamedbeili A.K. Sravnitel'naya kharakteristika porazhenii tsentral'noi nervnoi sistemy u novorozhdennykh s vnutriutrobnymi infektsiyami razlichnoi etiologii // Voprosy prakticheskoi pediatrii. - 2010. - №3. - S. 9596(In Russ.)]. 
6. Таранушенко Т.Е., Окунева О.С., Демьянова И.М. Уровни белков нейрональной и глиальной природы в крови новорожденных при церебральной ишемии. //Педиатрия 2010,том 89, № 1 , С. 25-31. [Taranushenko T.E., Okuneva O.S., Dem'yanova I.M. Urovni belkov neironal'noi i glial'noi prirody v krovi novorozhdennykh pri tserebral'noi ishemii. //Pediatriya 2010,tom 89, № 1, S. 25-31(In Russ.)].

7. Максутова А.К. Особенности системного воспалительного ответа у доношенных и недоношенных детей при врожденной инфекции ДНК- вирусной этиологии./ Автореферат. ... дисс.мед.наук. Новосибирск 2009, 44 с. [Maksutova A.K. Osobennosti sistemnogo vospalitel'nogo otveta $\mathrm{u}$ donoshennykh $\mathrm{i}$ nedonoshennykh detei pri vrozhdennoi infektsii DNK- virusnoi etiologii./ Avtoreferat. ... diss.med.nauk. Novosibirsk 2009, 44 s. (In Russ.)].

\section{8. Кравченко JI.B., Афонин А.А.} Особенности цитокинового статуса у детей первых месяцев жизни с генерализованной цитомегаловирусной инфекцией. // Педиатрия. Журнал им. Г.Н. Сперанского. - 2011. - Т.90, №1. C.39-43. [Kravchenko JI.B., Afonin A.A. Osobennosti tsitokinovogo statusa u detei pervykh mesyatsev zhizni s generalizovannoi tsitomegalovirusnoi infektsiei. // Pediatriya. Zhurnal im. G.N.
Speranskogo. - 2011. - T.90, №1. - S.39-43. (In Russ.)].

9. Zarkesh $\mathrm{M}^{1}$, Sedaghat $\mathrm{F}^{1}$, Heidarzadeh $\mathrm{A}^{2}$ et al. Diagnostic value of IL-6, CRP, WBC, and absolute neutrophil count to predict serious bacterial infection in febrile infants//Pediatr Int. $2016 \quad$ Feb;58(2):119-25. doi: 10.1111/ped.12754.

10. Çelik $\mathrm{HT}^{1}$, Portakal $\mathrm{O}^{2}$, Yiğit $\mathrm{S}^{1}$ et al Efficacy of new leukocyte parameters versus serum C-reactive protein, procalcitonin, and interleukin-6 in the diagnosis of neonatal sepsis. PLoS One. 2015 May 21;10(5):e0127170. doi: 10.1371/journal.pone.0127170. eCollection 2015.

11. Гараев В.Р., Зубарева О.Е., Шумилина M.В. Влияние содержания провоспалительных цитокинов в крови на повторную судорожную активность у новорожденных с гипоксически ишемической энцефалопатией // Нейрохирургия и неврология детского возраста, 2011, Т. 30, № 4,c. 49-51. [Garaev V.R.,Zubareva O.E., Shumilina M.V. Vliyanie soderzhaniya provospalitel'nykh tsitokinov $\mathrm{V}$ krovi na povtornuyu sudorozhnuyu aktivnost' $\mathrm{u}$ novorozhdennykh s gipoksicheski ishemicheskoi entsefalopatiei // Neirokhirurgiya i nevrologiya detskogo vozrasta, 2011, T. 30, № 4,c. 49-51. (In Russ.)]. 
Table 1.

Sonographic signs of cerebral pathology in premature newborns with perinatal infection..

\begin{tabular}{|c|c|c|c|c|c|}
\hline & $\begin{array}{l}\text { I group } \\
(n=220)\end{array}$ & $\begin{array}{l}\text { II group } \\
(n=118)\end{array}$ & $\begin{array}{l}\text { III group } \\
(\mathrm{n}=95)\end{array}$ & $\begin{array}{l}\chi^{2} \\
\mathrm{p}_{\mathrm{ku}}\end{array}$ & $\mathrm{F} ; \mathrm{p}$ \\
\hline $\begin{array}{l}\text { Hemodynamic changes } \\
\text { of ischemic nature: }\end{array}$ & $\begin{array}{l}133 * * * \\
52,0 \pm 3,8 \%\end{array}$ & $\begin{array}{l}77 * * * \\
65,3 \pm 4,4 \%\end{array}$ & $\begin{array}{l}57^{*} \\
60,0 \pm 5,0 \%\end{array}$ & $\begin{array}{l}\chi^{2}=48,4 \\
p<0,001\end{array}$ & $\begin{array}{l}F=17,9 \\
p<0,001\end{array}$ \\
\hline $\begin{array}{l}\text { Disorders of brain } \\
\text { circulation }\end{array}$ & $\begin{array}{l}89 \\
40,5 \pm 3,3 \%\end{array}$ & $\begin{array}{l}36 \\
37,1 \pm 4,9 \%\end{array}$ & $\begin{array}{l}29 \\
30,5 \pm 4,7 \%\end{array}$ & & \\
\hline Отек головного мозга & $\begin{array}{l}62 \\
28,2 \pm 3,0 \%\end{array}$ & $\begin{array}{l}13 \\
13,4 \pm 3,5 \%\end{array}$ & $\begin{array}{l}15 \\
15,8 \pm 3,7 \%\end{array}$ & & \\
\hline $\begin{array}{l}\text { Cerebral ischemia of II- } \\
\text { III degree }\end{array}$ & $\begin{array}{l}12 \\
5,5 \pm 1,5 \%\end{array}$ & $\begin{array}{l}1 \\
1,0 \pm 1,0 \%\end{array}$ & $\begin{array}{l}5 \\
5,3 \pm 2,3 \%\end{array}$ & & \\
\hline $\begin{array}{l}\text { Periventricular } \\
\text { leukomalacia }\end{array}$ & $\begin{array}{l}15 \\
6,8 \pm 1,7 \%\end{array}$ & $\begin{array}{l}2 \\
2,1 \pm 1,4 \%\end{array}$ & $\begin{array}{l}13 \\
13,7 \pm 3,5 \%\end{array}$ & & \\
\hline $\begin{array}{l}\text { Hemodynamic changes } \\
\text { of hemorrhagic nature: }\end{array}$ & $\begin{array}{l}58^{* *} \\
26,4 \pm 3,0 \%\end{array}$ & $\begin{array}{l}57 * * * \\
48,3 \pm 4,6 \%\end{array}$ & $\begin{array}{l}31 * * \# \\
32,6 \pm 4,8 \%\end{array}$ & $\begin{array}{l}\chi^{2}=30,5 \\
p<0,001\end{array}$ & $\begin{array}{l}\mathrm{F}=10,8 \\
\mathrm{p}<0,001\end{array}$ \\
\hline $\begin{array}{l}\text { Perivetricular } \text { Bleeding } \\
(\mathrm{PVB}) \text { I grade }\end{array}$ & $\begin{array}{l}36 \\
16,4 \pm 2,5 \%\end{array}$ & $\begin{array}{l}34 \\
28,8 \pm 4,2 \%\end{array}$ & $\begin{array}{l}21 \\
22,1 \pm 4,3 \%\end{array}$ & & \\
\hline (PVB) II grade & $\begin{array}{l}16 \\
7,3 \pm 1,8 \%\end{array}$ & $\begin{array}{l}20 \\
19,3 \pm 3,5 \%\end{array}$ & $\begin{array}{l}8 \\
8,4 \pm 2,8 \%\end{array}$ & & \\
\hline (PVB) III grade & $\begin{array}{l}6 \\
2,8 \pm 1,0 \%\end{array}$ & $\begin{array}{l}3 \\
2,5 \pm 1,4 \%\end{array}$ & $\begin{array}{l}2 \\
2,1 \pm 1,5 \%-\end{array}$ & & \\
\hline $\begin{array}{l}\text { Hemodynamic changes } \\
\text { of infectious nature: }\end{array}$ & $\begin{array}{l}34 \\
15,5 \pm 2,4 \%\end{array}$ & $\begin{array}{l}20 \\
16,9 \pm 3,5 \%\end{array}$ & $\begin{array}{l}18^{\wedge \wedge \wedge} \# \\
18,9 \pm 4,0 \%\end{array}$ & $\begin{array}{l}\chi^{2}=7,1 \\
p=0,069\end{array}$ & $\begin{array}{l}F=2,4 \\
p=0,068\end{array}$ \\
\hline Ventriculitis & $\begin{array}{l}33 * * \\
15,0 \pm 2,4 \%\end{array}$ & $\begin{array}{r}16 \\
13,6 \pm 3,2 \%\end{array}$ & $\begin{array}{l}16 \\
16,8 \pm 3,8 \%\end{array}$ & & \\
\hline Meningitis & $\begin{array}{l}2 \\
0,9 \pm 0,6 \%\end{array}$ & $\begin{array}{l}4 \\
3,4 \pm 1,7 \%\end{array}$ & $\begin{array}{l}3 \\
3,2 \pm 1,8 \%\end{array}$ & & \\
\hline Calcifications & $\begin{array}{l}9 \\
4,1 \pm 1,3 \%\end{array}$ & $\begin{array}{l}14 \\
11,9 \pm 3,0 \%\end{array}$ & - & & \\
\hline $\begin{array}{l}\text { Congential brain } \\
\text { developmental defect }\end{array}$ & $\begin{array}{l}2 \\
0,9 \pm 0,6 \%\end{array}$ & $\begin{array}{l}11 \\
0,8 \pm 0,8 \%\end{array}$ & $\begin{array}{l}2 \\
2,1 \pm 1,4 \%\end{array}$ & & \\
\hline Periventricular cysts & $\begin{array}{l}16 \\
7,3 \pm 1,8 \%\end{array}$ & $\begin{array}{l}21 \\
17,8 \pm 3,5 \%\end{array}$ & $\begin{array}{l}1 \\
1,7 \pm 3,6 \%\end{array}$ & & \\
\hline $\begin{array}{l}\text { Mineralising } \\
\text { vasculopathy }\end{array}$ & $\begin{array}{l}12 \\
5,5 \pm 1,5 \%\end{array}$ & $\begin{array}{l}16 \\
13,6 \pm 3,2 \%\end{array}$ & $\begin{array}{l}2 \\
2,1 \pm 1,4 \%-\end{array}$ & & \\
\hline
\end{tabular}


Ventriculomegaly

\begin{tabular}{l|l}
\hline 45 & 30 \\
$20,5 \pm 2,6 \%$ & $25,4 \pm 4,6 \%$
\end{tabular}

22

$23,4 \pm 4,4 \%$

Notes:

1. Statistical power of difference with the control group: ${ }^{*}-\mathrm{p}<0,05 ; * *-\mathrm{p}<0,01 ; * * *-$ $\mathrm{p}<0,001$.

2. CI $95 \%$ is given in the bracket (lower and upper limits). $\chi 2 ; p_{k u}-$ results of one-way analysis of variance by Kruskal-Wallis

3. F; p-results of one factor dispersion analysis per Fisher.

Table 2.

Neuroimmunological indicators of blood in premature newborns with perinatal infections.

\begin{tabular}{|c|c|c|c|c|c|c|}
\hline $\begin{array}{l}\text { Indicators, } \\
\text { Пг/мл }\end{array}$ & $\begin{array}{l}\text { Control } \\
\text { group }\end{array}$ & $\begin{array}{l}\text { I group } \\
(n=14)\end{array}$ & $\begin{array}{l}\text { II group } \\
(n=9)\end{array}$ & $\begin{array}{l}\text { III group } \\
(\mathbf{n}=\mathbf{2 1})\end{array}$ & $\chi^{2} ; \mathbf{p}_{\mathrm{ku}}$ & $\mathbf{F} ; \mathbf{p}$ \\
\hline IL-1 $\beta$ & $\begin{array}{l}2,8 \pm 0,2 \\
(2,4-3,2)\end{array}$ & $\begin{array}{l}14,2 \pm 2,5 \\
(8,8-19,5)\end{array}$ & $\begin{array}{l}9,5 \pm 1,9 \\
(5-13,9)\end{array}$ & $\begin{array}{l}21,8 \pm 3,4 \\
(14,2-29,3)\end{array}$ & $\begin{array}{l}\chi 2=27,0 \\
p<0,001\end{array}$ & $\begin{array}{l}\mathrm{F}=10,1 ; \\
\mathrm{p}<0,001\end{array}$ \\
\hline IL-6 & $\begin{array}{l}3,4 \pm 0,1 \\
(3,2-3,7)\end{array}$ & $\begin{array}{l}12,7 \pm 1,6 \\
(9,3-16,1)\end{array}$ & $\begin{array}{l}16,1 \pm 2,0 \\
(11,6-20,7)\end{array}$ & $\begin{array}{l}28,2 \pm 2,2 \\
(23,4-33,1)\end{array}$ & $\begin{array}{l}\chi 2=34 \\
p<0,001\end{array}$ & $\begin{array}{l}F=35,6 ; \\
p<0,001\end{array}$ \\
\hline NSE & $\begin{array}{l}6,0 \pm 0,8 \\
(4-12)\end{array}$ & $\begin{array}{l}20,3 \pm 1,3 \\
(7-29)\end{array}$ & $\begin{array}{l}29,6 \pm 2,5 \\
(14-41)\end{array}$ & $\begin{array}{l}20,3 \pm 1,9 \\
(7,9-31)\end{array}$ & $\begin{array}{l}\chi 2=20,3 \\
p<0,001\end{array}$ & $\begin{array}{l}\mathrm{F}=9,1 ; \\
\mathrm{p}<0,001\end{array}$ \\
\hline $\begin{array}{lr}\text { NSE repeat } \\
\text { testing }\end{array}$ & $\begin{array}{l}14,5 \pm 1,1 \\
(8-21,2)\end{array}$ & $\begin{array}{l}14,5 \pm 1,1 \\
(8-21,2)\end{array}$ & $\begin{array}{l}20,7 \pm 1,8 \\
(12,8-32)\end{array}$ & $\begin{array}{l}18,0 \pm 1,5 \\
(9,9-23,5)\end{array}$ & $\begin{array}{l}\chi 2=0,9 \\
p<0,001\end{array}$ & $\begin{array}{l}F=0,53 \\
p=0,006\end{array}$ \\
\hline
\end{tabular}

Notes:

1.Statistical power of difference with the control group: $*_{-} \mathrm{p}<0,05 ; * *-\mathrm{p}<0,01 ; * * *-\mathrm{p}<0,001$. CI 95\% is given in the bracket (lower and upper limits).

2. $\chi 2 ; p_{\mathrm{ku}}$ - results of one-way analysis of variance by Kruskal-Wallis

3.. F; $\mathrm{p}$ - results of one factor dispersion analysis per Fisher. 